\title{
Elwood Murray: Pioneering Methodologist in Communication
}

\author{
Judi Brownell \\ Cornell University
}

Final version published October 2014 in Communication Education, Vol. 63, No. 4, pp. 329-343.

\section{$\underline{\text { Author Note }}$}

Judi Brownell (Ph.D., Syracuse University) is a Professor in the School of Hotel Administration at Cornell University.

Correspondence to: Judi Brownell, School of Hotel Administration, Cornell University, 336 Statler Hall, Ithaca, NY 14853. Email: jlb18@cornell.edu. 
Elwood Murray (1897-1988) was a pioneer in communication education. Beginning in the 1930s, he applied nontraditional methods in the speech classroom to encourage students to internalize and apply what they learned, and to view knowledge holistically. Drawing on the work of Kunkel, Moreno, Lewin, and Korzybski, Murray focused on developing skills in interpersonal and group communication. He facilitated classroom activities that he believed would bring about positive change in students' personalities as well as enhance their relationships and leadership ability. Communication methodologies, he argued, could facilitate learning in all fields and foster interdisciplinary understanding. In spite of much skepticism by his colleagues, Murray introduced innovative classroom practices that advanced our thinking about instructional communication.

Keywords: Elwood Murray; Curriculum; Speech and Personality; Group Dynamics; General Semantics 


\section{Elwood Murray: Pioneering Methodologist in Communication}

"If I have seen farther than other men, it is because I have stood on the shoulders of giants (attributed to Isaac Newton)." So reads the opening quotation in the festschrift, a celebration publication presented to Elwood Murray on the occasion of his retirement from the faculty at the University of Denver in 1967 (Akin, Goldberg, Murray, \& Barnland, 1970, p. xii). That anthology recognized the pioneering work of a man who dedicated his career to advancing communication education and to introducing innovative instructional strategies through the development of what he called "communication methodology." The philosophies and methods that he introduced nearly 75 years ago continue to inform communication educators today as they confront similar classroom challenges and are inspired by similar goals.

Elwood Murray joined the Department of Dramatic Arts and Speech at the University of Denver in 1931 and soon became its chair. During the next 30 years, the department's philosophy and curriculum were shaped by Murray's conviction that speech was a broad and inherently interdisciplinary subject, and that speech education was essential for every individual. Murray emphatically maintained that the speech discipline was concerned with too small a portion of the total communication process. Over 60 years ago, he wrote, "... perhaps the development of sound programs of the teaching of communication ... requires that we extend the title of our academic programs from 'speech' to 'speech and communication' or 'communication'” (Murray, 1949, p. 239). Early in his career, Murray became convinced that traditional approaches to teaching speech were largely ineffective, as critical insights and behaviors were not being carried over into the students' everyday lives. Too often, he argued, students acquired a set of skills but lacked an appreciation of their application and value in a larger social context.

This paper highlights Elwood Murray's contribution to both communication education and instructional communication, and explains why his colleagues were indebted to him for his innovative and pioneering classroom practices. First, four major influences on the development of Murray's classroom methodologies are introduced. His applications of these methodologies are then organized around his three textbooks. 
Next, Murray's teaching is discussed as former students describe the effectiveness of his approach and the power of his personality. Clearly a pioneer, the final section illustrates how Murray's ideas and instructional practices have informed our current thinking and have had a direct and enduring impact on communication education and the teaching-learning process. A timeline of Murray's activities and accomplishments is presented in Table 1.

\section{Early Influences on Murray's Communication Methodology}

Above all else, Elwood Murray considered himself a speech educator. His lifelong interest was in discovering and applying classroom strategies that would help students internalize communication principles so that they could become more effective members of society. While "traditionalists" of the time focused on structured speech situations, the communication methodologist was concerned with facilitating less formal communication behaviors. Relying heavily on theory accumulated in the social sciences, the methodologist applied a range of instructional strategies to improve students' interpersonal communication in dynamic, informal contexts (Goldberg, 1967).

As Murray explained, "Applying the appropriate classroom methodology to help students internalize theory-that's what is critical. The difference between adding knowledge and changing behavior is great indeed, and the effective methodologist must have a variety of approaches" (Murray, interview, 1977). Practitioners of these methodologies, as the editors of Language Behavior suggested, would be instilling in their students the sensitivities and skills required to move into leadership positions in government, industry, and other organizations (Akin et al., 1970, p. 11).

Murray's belief in the interdisciplinary nature of communication led him to integrate ideas from a number of sources as he searched for ways to help students internalize sound communication practices. Four individuals, in particular, influenced the development of his methodologies; Fritz Kunkel, Kurt Lewin, Jacob Moreno, and Count Alfred Korzybski. 
One of the earliest influences on Murray's thinking was the work of Fritz Kunkel, who introduced Murray to his "We" psychology when he lectured at Estes Park during the summers of 1936 and 1937. A student of Adler and Freud, Kunkel's theories emphasized the importance of communication in developing positive, warm relationships. Murray quickly adopted Kunkel's notion that positive regard was essential to personal adjustment, and relied on Kunkel's theories as he formulated his own framework regarding the relationship between speech and personality (Kunkel, 1929, 1936).

In 1939, Murray was introduced to the methods of Jacob L. Moreno, a Viennese priest turned psychologist, who had been introducing "group approaches" in his work. Murray subsequently invited him to participate in Denver's summer programs and he became fascinated with the potential Moreno's ideas had for the speech classroom. Moreno's psychodrama, sociodrama, and sociometry techniques were to become central methodologies for Murray, approaches that he implemented in his classroom long before they became accepted practice. Murray believed that sociodrama, in particular, was well suited for the difficult task of helping students become more aware of their personal communication behaviors and subsequently become more effective in everyday communication situations (Moreno, 1946; Murray, 1948b).

Murray's work with Kurt Lewin in the 1940s at the National Laboratory for Group Development in Maine convinced him that group dynamics was also a powerful method for helping students internalize communication principles. Having experienced the effectiveness of Lewin's seminars as a participant, Murray incorporated extensive feedback opportunities and other group-oriented methods into his own offerings. Focus came to be placed on the group's process and interpersonal dynamics rather than on the problem-solving methods that characterized much group work in speech at the time (Lewin, 1935, 1947).

These three varied approaches were central to what would gradually develop into an extensive curriculum in Communication Methodology, required not only of students in that program but also of those faculty teaching Denver's mandatory freshman offering in Basic Communication (Murray, 1966). Murray believed that anyone teaching 
communication must be familiar with and skilled in process methodologies so that they could apply such techniques as role playing, feedback mechanisms, brainstorming, and sociodrama in their classrooms (Murray, Paul, \& Sorenson, 1946).

Perhaps of most significance, however, was the influence of Count Alfred Korzybski and the principles of general semantics on the development of Murray's thinking and teaching (Korzybski, 1933). In the summer of 1938, Murray was introduced to Marjorie Kendig, Korzybski's Educational Director. Murray was subsequently awarded five scholarships to attend Korzybski's intense, 2-week seminars at the General Semantics Institute in Chicago. Later, Murray invited Korzybski to the University of Denver on several occasions, including as a guest at the Congresses on General Semantics that were held in Denver in 1941 and 1949 (Murray, 1943).

Although Murray did not consider himself a "general semanticist," those who embraced Korzybski's principles were often looked upon by their more traditional speech colleagues as radical-even crazy. John Newman captured this sentiment in an article that appeared in the Quarterly Journal of Speech (Newman, 1961):

There are few things that seem to be more fun than taking pot shots at general semantics. It is a time honored sport, and after some twenty five or thirty years of it, the veteran observer has probably long since been witness to every possible variety thereof. (p. 158)

During the early 1940s, new courses continued to be added to Denver's speech curriculum (University of Denver, 1945). Gail Myers pointed out that by the end of that decade, Elwood Murray had introduced "the largest set of course offerings in speech in any academic institution" (Myers, 1964, p. 5). Courses in speech and personality adjustment, business and professional speaking, discussion, and speech science were readily available to Denver students. In 1948, offerings in intercultural and organizational communication had been added to the curriculum —clearly among the first courses in these subjects (housed within a speech curriculum) anywhere in the country (University of Denver, 1948). 
Throughout the next decade, additional offerings emerged and further strengthened Denver's communication methodology concentration. In 1954, for example, Sociodrama for Speech Situations appeared. The course description read: "Practice in role playing and group dynamics procedures for personal growth in speech situations. Through the application of sociometric and general semantics principles, the student learns to become a more effective team member" (University of Denver, 1954, pp. 113-114).

One of Murray's colleagues, Alvin Goldberg, noted in a 1960 report:

The major strength of the speech department at the University of Denver has been in the area of communication methodology ... due to the pioneering work of Elwood Murray, we have established a national reputation in the area of communication methods ... there is increased recognition across the country that the University of Denver's speech department has established itself as the strongest school in the nation in this new frontier of communication.

(Goldberg, 1960, p. 42)

\section{Classroom Applications of Communication Methodologies}

Murray's reputation as an innovator in communication education began with his earliest work in speech and personality. Throughout his career, Murray's textbooks captured his expanding view of a speech educator's goals, beginning with a focus on the individual student's speech personality (The Speech Personality; Murray, 1937b), then moving to explore the group's dynamic (Integrative Speech; Murray \& Paul, 1946), and ultimately addressing the challenge of interdisciplinary integration (Speech: Science-Art; Murray, Phillips, \& Truby, 1969). 


\section{The Speech Personality (1937): Methodologies to Foster Mental Objectivity}

Murray gained significant recognition, and generated significant controversy, through his early work on the relationship between speech and personality (Murray, 1934a, 1934b, 1935). Influenced not only by Fritz Kunkel but also by the training he received in holistic and organismal psychology as a graduate student at the University of lowa, Murray deepened and applied these ideas in his own work. In 1937, the year he became president of the Western Association of Teachers of Speech, Murray's first textbook, The Speech Personality, was published. In it, he outlined the relationship of personality to speech and suggested an approach to characterizing speech personality types. He believed that speech instruction could serve as personality therapy, and viewed the speech personality as growing out of and being reflected through an individual's communication behaviors. Instruction in speech, therefore, had a direct influence on the student's personality (Murray, 1937b).

As previously discussed, Murray had been deeply dissatisfied with speech courses as they were traditionally taught. The Speech Personality, perhaps one of the most controversial textbooks written in the 1930s, was designed to "make a difference" - not only in students' classroom performance, but also in their ability to adjust appropriately to everyday social situations. As Murray explained in an interview in 1971, "The need to write this book came with the realization that conventional speech education methods were failing to produce significant and lasting improvements in the communication of many students. The reason being that conventional methods did not reach the heart of the speaker's problem-his personality" (Adams, 1971, p. 28). Murray constructed a framework around four personality dimensions: mentally objective introverts, mentally objective extroverts, egocentric introverts, and egocentric extroverts (Table 2). The areas of adjustment necessary for mental objectivity included such dimensions as speaker attitude, emotional control, spontaneity and responsiveness, vocal quality and gestures, directness, and so forth (Murray, 1937b). Internalization of Korzybski's principles of general semantics was seen as the means by which students might develop greater mental objectivity and acquire the attitudes and habits of perception that encourage personal effectiveness. With insights from general 
semantics, Murray made proper evaluation the basis for an appropriate speech response. One of the most common maladjustments, he believed, resulted from students making words more important than the facts-placing their focus on the skills of presentation rather than on the content and ideas presented.

Murray's ideal leader would be a mentally objective extrovert who, as he described, would " $\ldots$ be proficient in sensing what the other person feels and what he evaluates as important. He tends to be very tactful and persuasive in his contacts ... Most important to him is the welfare of the group ..." (Murray, 1937b, p. 519). In 1939, the Murray-Miller Personal-Social Adjustment Inventory was published (Murray \& Miller, 1939), and this instrument, in combination with Murray's text, provided the classroom teacher with the means through which personality improvement could be achieved by facilitating carefully designed speech activities.

Murray's classroom was characterized by methods that were viewed as novel at that time but have since become familiar practices for educators both in and outside of the communication discipline (Murray, 1941). Instruction was individualized according to speech-personality needs, with projects tailored to help each student attain greater personal adjustment and move toward increased mental objectivity (Murray, 1937b). Murray had no doubt that, to be effective, speech education must be personalized as each student's unique past experiences influenced his or her attitudes and behavior. Students were asked questions such as:

With what sort of persons do you most dislike to talk?

In what sort of situations are you most likely not to control the amount of talking you do?

In what situations are you most self-conscious? (Murray, 1937b, p. 348)

Because personality was so closely related to speech, all possible measures were taken to ensure that the student received a favorable response to each performance, and extensive feedback was provided so that individuals had specific communication goals. Students, in fact, were not allowed to participate in classroom activities or deliver speeches if Murray judged that they were poorly prepared. He 
strongly believed that a student's attitude toward the speech situation was a main indicator in determining the extent of improvement that could be made and the likelihood that newly acquired skills would be appropriately applied in out-of-class situations.

Clearly, The Speech Personality was revolutionary. Published in lithograph form and used in Denver's speech fundamentals classes from 1934 until the first printing of the text by J. B. Lippincott in 1937, it was subsequently adopted for Denver's required freshman Basic Communication course so that every student was exposed to Murray's ideas and approach (Brownell, 1978; Murray, 1934a).

\section{Integrative Speech (1946): Methodologies to Facilitate Group Dynamics}

Perhaps Elwood Murray's most noteworthy application of social science methodologies was his Laboratory in Interpersonal Communication, designed to help students internalize the principles of general semantics (Brownell, 1982). The laboratory was first offered as part of Denver's speech program in 1948 and is one of the best examples of the application of process methodologies to address principles of interpersonal communication and group dynamics. Murray described the dual goals of the seminar as "training in leadership and training in human relations" (Murray, 1955, p. 1). In 1948, Murray again lamented the ineffectiveness of traditional methods for instilling leadership competencies, as he wrote, "we seem unable to assess the social forces with which we must deal; we have brought our resources and technologies to bear too late and too meagerly, and not always to the right places, and not always the right resources ..." (Murray, 1948a, p. 83). To address these challenges, Murray designed a student experience that he hoped would facilitate the development of the leadership skills necessary to build positive relationships and respond appropriately to complex speech situations.

The principles of general semantics were, once again, at the heart of Murray's classroom practices; he believed the key to effectiveness was the ability to communicate about communication. Through a combination of lectures, experiential 
activities, and class discussions, laboratory sessions were carefully designed, applying a variety of methods and involving students in a range of experiential learning activities (Murray, 1944). Feedback was generated on as many levels as possible; for example, at the end of each class, students answered questions regarding their satisfaction with the session and provided recommendations for modifications in the design. This written feedback was summarized by a "feedback chair" and later discussed by the entire class.

Another unique feature of each session was the laboratory groups Murray created to correspond with Korzbyski's three levels of abstraction. Each group was responsible for preparing and presenting a specific type of project that illustrated the day's material. The group members concerned with the lowest level of abstraction were the picture makers, who created a series of drawings to illustrate the relevant concepts nonverbally. The sociodrama group would then role-play a communication problem related to the lecture material using such techniques as alter egos, hidden agendas, and soliloquies to illustrate their points. Finally, the forum discussion group operated at the highest level of abstraction and planned a panel involving the entire class in a discussion of various issues and applications of the material. Group members were assigned roles that fostered multiple perspectives in order to generate insights and lively dialogue. Finally, an observer was identified within each of the three groups whose task it was to watch member behaviors during the project planning process as well as the reactions of class members to each presentation. These observers then reported their findings to the class for further discussion (Brownell, 1982; Murray, 19501954).

Murray viewed these laboratory experiences as "integrative;" his hope was that they would bring individuals together around important issues in a world of constant change and uncertainty. His second textbook, Integrative Speech, focused on the principles and methods required to meet this challenge (Murray \& Paul, 1946). At this time, interpersonal communication was just beginning to be recognized by speech professionals as a significant focus of concern. Integrative Speech viewed speech not only as a form of individual expression, but as a powerful instrument for improving the process of human interaction and team development (Murray, 1937a, 1948a). Murray's 
laboratory approach, applying a portfolio of innovative methodologies, presented a far greater range of opportunities and challenges than could be found in the traditional classrooms of educators who viewed speech as predominantly public address. In fact, Murray commented that his first two textbooks "aroused controversy no less than they were ignored by the more conservative of the speech establishment" (Murray, taperecorded interview, January 15, 1976).

But even as the Laboratory in Interpersonal Communication was defining speech education at Denver, Murray was looking to apply his portfolio of methods to yet another innovative offering. His long-standing belief in the need for greater integration of knowledge and his conviction that speech was both science and art led him once again to apply his methodologies creatively.

\section{Speech Science-Art (1969): Methodologies to Promote the Integration of Knowledge}

Murray placed much of the blame for students' inability to think holistically on the structure and goals of traditional educational institutions. Forced into narrow channels of study, he believed students' vision was often limited by the assumptions of a particular discipline, preventing them from recognizing relationships or acquiring an integrated view of the world. As noted earlier, encouraging greater interdisciplinary communication had been one of the driving themes of Murray's teaching career.

In the mid-1950s, Murray formulated a plan to achieve his goal through a laboratory experience available to both students and faculty from throughout the university. He called this innovative design the Interdisciplinary Analogue Laboratory (Brownell, 1979; Murray \& Purdue, 1956). Murray believed that relationships among structures and processes from various disciplines could be discovered through the building of analogues. When a basic structure is identified within one discipline, it could then serve as a model on which to build an analogue in some other field.

In essence, the laboratory operated by gathering together individuals with different backgrounds-humanities, arts, science, social sciences-who then served as 
resources for one another as the group developed analogues among events and processes from different fields of inquiry. An analogue model, Murray proposed, would allow familiar structures to be used as a basis for understanding or discovering new insights about a less understood concept. He believed that the most useful and provocative analogues came from dissimilar disciplines, prompting participants to brainstorm and explore ideas not previously considered.

Once again, Murray applied a range of methodologies as participants engaged in lively discussion regarding the relationships among concepts in their respective fields. A set of prepared questions served as a catalyst; students were asked, for instance, "How are the principles of magnetism demonstrated throughout history? In literature? In human relationships?" (Murray, 1966). Laboratory groups were required to establish evaluation criteria as well as to summarize and present their work before the entire class. Sociodrama, role playing, and other group dynamics techniques became central to the learning experience. In order to conduct a successful analogue laboratory, the instructor needed not only the broadest possible background but also knowledge of general semantics and the methodologies to facilitate this multifaceted laboratory experience. Murray was convinced that the dynamic process methodologies he applied in the communication classroom had broad application across the curriculum. By encouraging colleagues from other disciplines to adopt similar approaches, Murray made a distinct and lasting contribution to instructional communication.

Not surprisingly, there were many who viewed the laboratory with skepticism. Even Murray himself recognized that he was moving into uncharted territory, confessing:

I had the idea for the analogue laboratory about five or ten years before I tried it. I didn't have nerve enough to put it down as a course ... I was scared to take it through a committee of specialists. Boy, that's the last thing that they would accept! (interview, June 27, 1977)

Ultimately, Murray once again charged forward with an offering that he felt was valuable in developing both students' critical and creative capacities, a synthesis that would 
become the theme of his third and final textbook, Speech: Science-Art (Murray, Phillips, \& Truby, 1969).

Throughout the next decade, exposure to the concepts of cybernetics and what was to become general systems theory inspired Murray to continually broaden his lens. He saw the principles of integration at work not only within and among individuals, but in all multilevel systems. Speech: Science-Art reflected this general systems perspective and presented one of the first relational models of communication. Murray continually encouraged others to adopt this relational orientation, maintaining that as society becomes increasingly complex, individuals become specialists and fail to recognize the connectedness of all knowledge.

\section{Murray's Influence on Students}

Clearly, Murray can and should be considered a pioneering speech educator who also contributed very directly to the development of instructional communication by looking beyond the traditional boundaries of the field for innovative and often powerful teaching strategies that could be applied both in and outside of the speech classroom. In 1977, Murray's former students were asked to identify what they believed to be the distinguishing features of his instruction. A recurring theme was the belief that Elwood Murray had received far too little credit for his progressive thinking and his pioneering classroom practices. Sample student comments appear in Table 3.

In 1976, two of Murray's former students, Dr. Gail Myers and his wife Michele Tolela, wrote a textbook in interpersonal communication based largely on the content and methods of Murray's Laboratory in Interpersonal Communication. In the preface of their text, The Dynamics of Human Communication: A Laboratory Approach (Myers \& Myers, 1976), the authors credited their mentor:

... this book has been influenced so directly by one person that a special tribute must be paid here. The behavioral approach which we have used is a reflection of the earliest pioneering efforts of Elwood Murray at the University of Denver. Three decades or more ahead of his colleagues, Elwood Murray wrote of the 
human element in the communicative act when most of the speech discipline was still involved with elocution. (1976, p. xix)

Much has been written over the years about the influence of an educator's personality on instructional effectiveness. Murray's impact was enhanced by a boundless enthusiasm for teaching and a sincere confidence in his students that encouraged them to try new ideas and test the limits of their abilities. In addition, Murray was never overly concerned about what others thought of his ideas. He was, as one colleague noted, "a bit of a character ... he had that twinkle in his eye, he was way out there, thinking thoughts that really weren't respectable in those days" (K. G. Johnson, personal letter, January 12,1978$)$. Another insight was provided by a former student, who wrote:

He drove this little Izetta—kind of a three-wheeler-around campus for a while ... he was probably the only one who would dare get into one of those things. $\mathrm{He}$ would go zipping around ... It sort of symbolized his independence. He was willing to do what he thought needed to be done, and if something made sense to him he did it. (D. E. Washburn, personal letter, September 2, 1977)

Had Murray been seeking popularity, he would certainly not have held fast to some of his ideas, many of which fell under heavy criticism. He was viewed as a rebel, a maverick, pursuing nontraditional instructional strategies that many at the time believed were inappropriate.

\section{Murray's Influence on Thinking and Practice in Communication}

Educators today owe much to the pioneers who contributed to our communication heritage, to the "giants" whose visions have shaped our current practices and enriched our understanding of the teaching-learning process. Elwood Murray's portfolio of methodologies to improve both students' communication 
competence and teaching effectiveness has made a significant contribution to both communication education and instructional communication.

We have always been, at heart, a discipline concerned with classroom effectiveness. When our national association was founded in 1914, its title included "teachers of public speaking." In 1975, the Speech Teacher was renamed Communication Education, offering an expanded focus and becoming the primary outlet for instructional communication research (Myers, 2010). Yet, it was not until 1997, nearly 50 years after Murray suggested the term "communication," that the national association formally recognized the need to apply its best practices to a wider range of settings as it adopted its current name, the National Communication Association.

As Murray predicted, an increasingly connected and complex world requires that individuals in all disciplines demonstrate effective communication practices. While Denver's basic communication course ensured that every student received communication instruction, many universities today still do not include communication in students' general education requirements. While few would argue the need for these skills, budget concerns, academic politics, and a lack of strong advocacy have often prevented Murray's dream of communication for all students from being fully realized. In spite of repeated attempts, programs designed to address communication across the curriculum have seldom resulted in lasting curricular change. Much work remains as educators strive to design collaborative approaches and to ensure that all students acquire communication competencies.

Murray's efforts to enroll faculty from throughout the university in his laboratories so that they could become skilled in "process methodologies" was an early recognition of the central role communication plays in the teaching-learning process. While researchers in instructional communication have focused on a range of topics, Murray was among the first to recognize the importance of classroom dynamics in achieving learning outcomes regardless of the subject matter.

The social science methods that Murray introduced continue to enhance instructional effectiveness across disciplines. His laboratories remain among the most comprehensive systems for generating and using feedback in an academic setting. 
Even as distance technologies change the nature of the teacher-student relationship, the increasing shift to blended learning attests to the value of dimensions Murray fostered: individualized instruction, team dynamics, and instructor involvement. While the term "general semantics" is seldom used, educators in all fields share the goal of helping students to gain mental objectivity and demonstrate the principles of clear thinking that Murray emphasized from his earliest years at Denver. Increasing diversity has led to an even greater need for individuals to develop competencies best acquired through process methodologies.

Successful business programs, for instance, are now characterized by experiential learning activities, team projects, and internships. In addition, educators recognize that tomorrow's leader must first be self-aware; consequently, management programs frequently provide students with assessment instruments and individualized goals not unlike Murray's activities in the speech personality classroom. Increasing attention is also being paid to other personal dimensions Murray recognized as critical, such as the impact of emotions and attitudes on behavior. Both emotional and cultural intelligence (Earley \& Ang, 2003; Goleman, 2011) have become key areas of interest, especially among those preparing to interact in global teams. Servant leadership, distinguished by its emphasis on providing support to followers, is another natural extension of Murray's belief in the importance of developing positive relationships and focusing on the welfare of the group.

Finally, Murray had hoped that efforts to integrate knowledge would expand and that his students would build upon their analogue laboratory experience. While pockets of structured interdisciplinary activity exist, universities continue to struggle with silos of learning that challenge cross-disciplinary understanding. As specialization has increased, each field has developed its own vocabulary, methods, and perspectives. We have witnessed far too many examples of the problems Murray anticipated in bringing our collective wisdom to bear on critical social problems. Technology and social media have facilitated the dissemination of information, making the principles of general semantics that Murray embraced more relevant than ever. Clearly, many of Murray's ideas resonate today as we come to appreciate his prescience and build on his legacy. 


\section{Conclusion}

Elwood Murray was a pioneering educator who believed that every student should receive communication instruction and that communication methodologies could be applied in every field. His nontraditional classroom practices encouraged students to view themselves and their language behavior with increased objectivity, to internalize and apply what they learned, and to think and perceive relationally so that productive outcomes would result. That his views were frequently misunderstood, that he was often criticized by his peers, did not prevent Elwood Murray from channeling his full energies into what he believed to be his greatest contribution. Such dedication was recognized by Andrew Weaver in his praise of the founding fathers of our national communication association when he declared, "The history of mankind bears eloquent testimony to the fact that a mere handful of individuals who are obedient to a great vision can shake the world" (Weaver, 1959, p. 199). Elwood Murray followed his vision with courage and conviction, and in the process made a significant contribution to the history of communication education and instructional effectiveness. 


\section{References}

Adams, B. (1971). Elwood Murray—A pioneer in speech communication (Unpublished master's thesis). Brigham Young University, Provo, UT.

Akin, J., Goldberg, A., Murray, E., \& Barnland, D. C. (Eds.). (1970). Language behavior: A book of readings in communication. Paris, The Hague: Mouton.

Brownell, J. L. (1978). Elwood Murray: A case study in educational integration and innovation (Unpublished dissertation). Syracuse University, Syracuse, NY.

Brownell, J. L. (1979). Elwood Murray's interdisciplinary analogue laboratory. Communication Education, 28, 9-21. doi:10.1080/03634527909378326

Brownell, J. L. (1982). Elwood Murray's laboratory in interpersonal communication. Communication Education, 31, 325-332. doi:10.1080/03634528209384700

Earley, P. C., \& Ang, S. (2003). Cultural intelligence: Individual interactions across cultures. Redwood City, CA: Stanford Business Books.

Goldberg, A. A. (1960). Assumption \#31, Report of the Denver Retreat (Unpublished document). Denver, CO: University of Denver.

Goldberg, A. A. (1967, October). Communication methodology. Paper presented at the Communication Colloquium, Milwaukee, WI.

Goleman, D. J. (2011). Leadership: The power of emotional intelligence. Florence, MA: More Than Sound.

Korzybski, A. H. S. (1933). Science and sanity: An introduction to non-Aristotelian systems and general semantics. Lakeville, CT: The International Non-Aristotelian Library Publishing.

Kunkel, F. (1929). Let's be normal: The psychologist comes to his senses. New York, NY: Ives Washburn.

Kunkel, F. (1936). Conquer yourself: The way to self-confidence. New York, NY: Ives Washburn.

Lewin, K. Z. (1935). Dynamic theory of personality. New York, NY: McGraw-Hill.

Lewin, K. Z. (1947). Frontiers in group dynamics: Concept, method, and reality in social science. New York, NY: McGraw Hill.

Moreno, J. L. (1946). Psychodrama. Beacon, NY: Beacon House Publishers. 
Murray, E. P. (1934a). The basic speech course and the speech personality. Reevaluation of the place of speech in the educational process. In E. Ralph Nichols (Ed.), Proceedings of the Western Association of Teachers of Speech Convention. Redlands University, CA.

Murray, E. P. (1934b). Speech training as a mental hygiene method. The Quarterly Journal of Speech, 20, 37-47. doi:10.1080/00335633409379996

Murray, E. P. (1935). Studies in speech and personality. Speech Monographs, 2, 50 63. doi:10.1080/ 03637753509374828

Murray, E. P. (1937a, November). Speech as a social integrator. Proceedings of the Ninth Annual Convention of the Western Association of Teachers of Speech (pp. 25-27), Denver, CO.

Murray, E. P. (1937b). The speech personality. New York, NY: J. B. Lippincott.

Murray, E. P. (1941). Manual of individual and class projects for the development of the speech personality. New York, NY: J. B. Lippincott.

Murray, E. P. (1943). The significance of general semantics in speech education.

Western Speech, 13, 1-8.

Murray, E. P. (1944). Communication dynamics book. Denver, CO: University of Denver Press.

Murray, E. P. (1948a). Personality, communication, and interpersonal relations. The Southern Speech Journal, 13, 79-83.

Murray, E. P. (1948b). Communication and interpersonal relations: Sociodrama and psychodrama in the college Basic Communication class. Sociatry, 2, 322-333.

Murray, E. P. (1949). Speech in the total school curriculum. The Southern Speech Journal, 14, 233-241.

Murray, E. P. (1950-1954). The laboratory in interpersonal communication. Notebooks containing syllabi, notes, and activities from offerings during the years 19501954. Denver, CO: University of Denver.

Murray, E. P. (1955). The laboratory in interpersonal communication. Brochure on the Laboratory in Interpersonal Communication. Denver, CO: University of Denver. Murray, E. P. (1966). The University of Denver laboratory and program in communication methodology. In Elwood Murray (Ed.), The student as speaker 
and listener. Proceedings of the Conference on Communication Skills and Interpersonal Relations. Yellow Springs, $\mathrm{OH}$ : Antioch College Press.

Murray, E. P., \& Miller, L. W. (1939). The Murray-Miller personal-social adjustment inventory. Denver, CO: University of Denver Press.

Murray, E. P., \& Paul, W. B. (1946). Integrative speech. New York, NY: John S. Swift and Company, Inc.

Murray, E. P., Paul, W. B., \& Sorenson, F. (1946). A functional core for the Basic Communication Course. The Quarterly Journal of Speech, 32, 232-244.

Murray, E. P., Phillips, G. M., \& Truby, D. J. (1969). Speech: Science-art. New York, NY: The Bobbs-Merrill Company.

Murray, E. P., \& Purdue, J. E. (1956). General semantics in an interdisciplinary educational program: Plan for a laboratory in the integration of knowledge. Etc.: A Review of General Semantics, 14, 38-46.

Myers, G. E. (1964, March). A new approach-the laboratory in interpersonal communication. Paper presented in honor of Elwood Murray at a National Society for the Study of Communication luncheon, San Francisco, CA.

Myers, G. E., \& Myers, M. T. (1976). The dynamics of human communication: A laboratory approach. New York, NY: McGraw-Hill.

Myers, S. A. (2010). Instructional communication: The emergence of a field. In D. L. Fassett \& J. T. Warren (Eds.), The Sage handbook of communication instruction (pp. 149-159). Thousand Oaks, CA: Sage.

Newman, J. B. (1961). General Semantics and academic phagocytosis. The Quarterly Journal of Speech, 47, 158-163.

University of Denver. (1945). University of Denver course catalogue 1945-1946.

Denver, CO: University of Denver.

University of Denver. (1948). University of Denver course catalogue 1948-1949.

Denver, CO: University of Denver.

University of Denver. (1954). University of Denver course catalogue 1954-1955.

Denver, CO: University of Denver.

Weaver, A. T. (1959). Seventeen who made history-The founders of the Association. The Quarterly Journal of Speech, 45, 195-199. 
Table 1. Time Line of Elwood Murray's Activities and Accomplishments.

\begin{tabular}{ll}
\hline 1931 & $\begin{array}{l}\text { Received Ph.D. in speech and psychology from the University of } \\
\text { lowa, the third Ph.D. in speech awarded in the country } \\
\text { Joined the Department of Dramatic Arts and Speech at the University } \\
\text { of Denver }\end{array}$ \\
1931 & $\begin{array}{l}\text { Introduced to Fritz Kunkel's "We" psychology } \\
1936\end{array}$ \\
1937 & $\begin{array}{l}\text { Became President of the Western Speech Association } \\
1937\end{array}$ \\
1938 & $\begin{array}{l}\text { First edition of The Speech Personality published } \\
\text { Introduced to Alfred Korzybski and the principles of General }\end{array}$ \\
1939 & $\begin{array}{l}\text { Semantics } \\
\text { Publication of the Murray-Miller Personal-Social Adjustment }\end{array}$ \\
1939 & $\begin{array}{l}\text { Inventory } \\
\text { Introduced to Jacob Moreno's social science methods }\end{array}$ \\
1941 & $\begin{array}{l}\text { Organized first Congress on General Semantics at the University of } \\
\text { Denver }\end{array}$ \\
1943 & $\begin{array}{l}\text { Studied with Kurt Lewin at the National Laboratory for Group } \\
\text { Dynamics }\end{array}$ \\
1946 & $\begin{array}{l}\text { First edition of Integrative Speech published } \\
\text { Laboratory in Interpersonal Communication offered at the University } \\
1948\end{array}$ \\
1948 & $\begin{array}{l}\text { of Denver } \\
\text { Courses in Intercultural \& Organizational communication added to }\end{array}$ \\
1956 & $\begin{array}{l}\text { Denver's curriculum } \\
\text { Interdisciplinary Analogue Laboratory offered at the University of }\end{array}$ \\
1967 & $\begin{array}{l}\text { Denver } \\
\text { Retired from the University of Denver } \\
\text { Language Behavior published, festschrift in Murray's honor }\end{array}$ \\
1967 & First edition of Speech: Science-Art published \\
\hline
\end{tabular}


Table 2. Dimensions of Murray's Speech Personality As They Impact Communication Behavior

\begin{tabular}{|c|c|c|c|}
\hline Egocentric introvert & Egocentric extrovert & $\begin{array}{c}\text { Mentally objective } \\
\text { introvert }\end{array}$ & $\begin{array}{c}\text { Mentally objective } \\
\text { extrovert }\end{array}$ \\
\hline $\begin{array}{l}\text { Fear of new speech } \\
\text { situations }\end{array}$ & $\begin{array}{l}\text { Little fear; may be } \\
\text { boldly audacious }\end{array}$ & Careful preparation & $\begin{array}{l}\text { Forceful, natural } \\
\text { leader }\end{array}$ \\
\hline Self-conscious & $\begin{array}{l}\text { No self- } \\
\text { consciousness }\end{array}$ & $\begin{array}{l}\text { Solicitous of } \\
\text { refinements }\end{array}$ & Extremely poised \\
\hline Feels inferior & $\begin{array}{l}\text { Feels superior to } \\
\text { others }\end{array}$ & Tactful, gracious & $\begin{array}{l}\text { Powerful in } \\
\text { persuasion }\end{array}$ \\
\hline $\begin{array}{l}\text { Mental blocks, } \\
\text { inhibitions }\end{array}$ & $\begin{array}{l}\text { Little organization; } \\
\text { says whatever comes } \\
\text { to mind }\end{array}$ & No faux pas & Adapts to audience \\
\hline $\begin{array}{l}\text { Worries over } \\
\text { preparation }\end{array}$ & $\begin{array}{l}\text { Prepares poorly, } \\
\text { attempts to bluff }\end{array}$ & Humor at a high level & $\begin{array}{l}\text { Does not disregard } \\
\text { details }\end{array}$ \\
\hline $\begin{array}{l}\text { Little sense of humor } \\
\text { Low level of humor }\end{array}$ & $\begin{array}{l}\text { Appropriate level of } \\
\text { humor }\end{array}$ & Inspires loyalty & \\
\hline $\begin{array}{l}\text { Prone to mannerisms } \\
\text { and affectations }\end{array}$ & Shallow thinker & Makes a contribution & Speaks directly \\
\hline Strained in action & $\begin{array}{l}\text { Always has the last } \\
\text { word }\end{array}$ & $\begin{array}{l}\text { Accurate information } \\
\text { Excellent sense of } \\
\text { humor }\end{array}$ & \\
\hline $\begin{array}{l}\text { Monotonous, } \\
\text { colorless }\end{array}$ & $\begin{array}{l}\text { Given to bombastic } \\
\text { assertiveness }\end{array}$ & Clear organization & $\begin{array}{l}\text { Thinks effectively } \\
\text { impromptu }\end{array}$ \\
\hline
\end{tabular}


Table 3. Sample Student Comments on Murray's Teaching

- He was always seeking the best, innovating ... his ability to adjust, meet new conditions, examine and study new ideas was ever present in his classes. (Page, F., personal letter, August 25, 1977)

- Murray was a man with a vision who saw something of great value and brought it into academia and gave it respectability ... a man who understood the value of the original thinking and who was able to develop it in an academic context. (Washburn, D., personal letter, September 2, 1977)

- I went to Denver in 1952 to get my Ph.D. because that was the place where new things were going on in the field of speech called communication and I wanted to move in the 'new direction.' Dr. Elwood Murray was the pioneer in this field ... (Wiseman, G., personal letter, October 3, 1977)

- Long before the proliferation of groups dedicated to the sensitization of participants to their own and others' behavior, Dr. Murray offered an effective approach that preserved the dignity of the participants while pointing out communication areas needing adjustment ... Dr. Murray is, indeed, a "man before his time." He has dared to dream of affecting a broad mix from many minds at many levels. Dr. Murray dares to be different. (Vaughn, G., personal letter, September 15, 1977) 